УДК 347.996

DOI https://doi.org/10.32849/2663-5313/2020.11.08

\title{
Анжеліка Шеремет,
}

аспірант кафедри чивільно-правових дисииплін

Навчально-наукового інституту права імені Іоаннікія Малиновського

Національного університету «Острозъка академія»

\section{ЗАКОНОДАВЧЕ РЕГУЛЮВАННЯ МЕДІАЦІЇ В УКРАЇНІ: АНАЛІЗ ПРОЄКТУ ЗАКОНУ УКРАЇНИ «ПРО МЕДІАЦІЮ»}

Стаття присвячена дослідженню міжнародного та начіонального досвіду правового регулювання медіації та на його основі аналізу проєкту Закону «Про медіацію» № 3504 задля пошуку шляхів його вдосконалення. Визначено, шо прочес гармонізачії начіонального законодавства відповідно до вимог законодавства Європейського Союзу вимагає впровадження альтернативних судовому способів врегулювання спорів.

Медіачії властиві такі ознаки: наявність правового спору між сторонами; вирішення спору та винесення рішення безпосередньо сторонами; наявність третьої особи - медіатора, який сприяє налагодженню комунікації між сторонами, однак не вирішує спір фактично; наявність медіаційної угоди, яка виконується добровільно або примусово, у разі ї̈ затвердження судом.

Зроблено висновок, що проєкт Закону «Про медіацію» № 3504 загалом відповідає міжнародним та новітнім начіональним практикам впровадження медіачії $і \epsilon$ необхідним для поширення альтернативних способів врегулювання спору, а модель медіаиї, яка пропонується законопроєктом, є найбільш оптимальною і допускає застосування медіації як на етапі перед/замість звернення до юрисдикиійних органів, так $і$ як спосіб примирення сторін судового прочесу.

Загалом в юридичній літературі виділяють різні моделі медіачії, які різняться за прочедурою розгляду, відображають різноманітні теорії, види й стратегії. В Україні пропонується запровадити модель, де медіатор виступає в ролі організатора вирішення конфлікту.

Запропоновано передбачити можливість проведення медіачї̈ кількома медіаторами одночасно; визначити поняття сторони медіації, моменту, з якого особа набуває такого статусу; зазначити можливість здійснення медіачії адвокатами чи нотаріусами; визначити правовий статус об'єднань медіаторів; передбачити принаймні найбільш важливі сфери, де медіачія не може бути застосована; використовувати поняття «спір» для позначення сфери його застосування; визначити засади взаємодії медіаторів та відповідних юрисдикиійних органів; передбачити правові наслідки укладення угоди за результатами медіації.

Ключові слова: медіація, альтернативні способи вирішення спорів, конфлікт, спір, угода, медіаційна угода, медіатор, законопроєкт.

Постановка проблеми. В Україні нагальною є проблема забезпечення доступу до правосуддя з огляду на завантаженість судової системи, яка з різних причин не справляється зі значною кількістю спорів. Водночас процес гармонізації законодавства України 3 європейським законодавством вимагає забезпечення відповідності національної правової системи стандартам ЄС.

У світовій практиці загального поширення набувають практики застосування для врегулювання різних конфліктів інструментів альтернативного врегулювання спорів (ABC) чи Alternative Dispute Resolution (ADR). C. Esplugues, розглядаючи нові події у сфері посередництва, зазначає, що безперервний ріст рівня судових спорів тисне на всю судову систему, що впливає на трива- лість розгляду та призводить до зростання витрат, що заважає доступу до суду [1].

Європейський Союз у Директиві «Про деякі аспекти медіації у цивільних та комерційних справах» 2008\52\ЕС [2] рекомендував запровадження й закріплення на законодавчому рівні медіації як одного з основних методів альтернативного врегулювання спору на досудовому етапі та під час судового оскарження. В Україні запровадження правового регулювання медіації перебуває на етапі законопроєктної роботи. 15 липня 2020 року Верховна Рада в першому читанні прийняла за основу проєкт Закону «Про медіацію» № 3504, внесений Кабінетом Міністрів України [3]. Отже, необхідно проаналізувати цей проєкт Закону 3 огляду на міжнародний та національний досвід регулювання медіації. 
Окремі питання правового регулювання медіації досліджено у працях таких науковців, як Т. Кисельова, Я. Любченко, Н. Мазаракі, Г. Огренчук, Ю. Притика, С. Фурса. Водночас актуальним залишається питання гармонізації законодавства України з європейським законодавством, зокрема щодо впровадження альтернативних способів врегулювання спору.

Метою статті є визначення міжнародного та національного досвіду правового регулювання медіації та на його основі аналізу законопроєктів про медіацію задля пошуку шляхів їх удосконалення. Для вирішення поставленої мети реалізовано такі завдання, як аналіз поняття медіації в теоpiї та законодавстві, визначення переваг та недоліків законопроєкту щодо медіації.

\section{Виклад основного матеріалу.}

Поняття, ознаки та моделі медіаиї.

Медіація як альтернативний спосіб врегулювання спорів (конфліктів) набуває все більшого поширення практично в усіх державах світу, зокрема в Україні. Досвід впровадження медіації у зарубіжних країн та перші спроби й перспективи впровадження медіації в Україні, а також перші законопроєкти вже були предметом розгляду [4]. Водночас поняття медіації в проєкті Закону «Про медіацію» № 3504 є відмінним від попередніх. Медіація визначена як добровільна, позасудова, конфіденційна, структурована процедура, під час якої сторони за допомогою медіатора (медіаторів) намагаються врегулювати конфлікт (спір) шляхом переговорів.

Таке визначення медіації враховує досвід інших національних законів. Так, Закон Республіки Молдова «Про медіацію» від 14 червня 2007 року визначає медіацію як альтернативний спосіб вирішення конфлікту між сторонами за взаємною згодою за допомогою третьої особи [5]. Стаття 2 Закону Республіки Казахстан «Про медіацію» від 28 січня 2011 року визначає медіацію як процедуру врегулювання спору (конфлікту) між сторонами за сприянням медіатора (медіаторів) задля досягнення ними взаємоприйнятного рішення, що реалізується за добровільною згодою сторін [6].

Відповідно до статті 1 Закону Республіки Білорусь «Про медіацію» від 12 червня 2013 року, медіація - це переговори сторін за участю медіатора задля врегулювання спору (спорів) сторін шляхом напрацювання ними взаємоприйнятного рішення [7].

Директива 2008/52/ЕС є основою для визначення медіації в країнах Європейського Союзу. Так, відповідно до Стандартів проведення медіації Республіки Польща від 26 червня 2006 року, під медіацією розуміють добровільний та конфіденційний процес, у якому фахово підготовлена незалежна стороння особа за згодою сторін допомагає їм вирішити конфлікт [8]. Закон Республіки Болгарія про медіацію від 17 грудня 2004 року визначає медіацію як добровільну та конфіденційну процедуру позасудового вирішення спору, під час якої третя особа (медіатор) допомагає сторонам у досягненні згоди [9]. Закон Німеччини про медіацію від 21 липня 2012 року визначає медіацію як конфіденційний та структурований процес, у ході якого сторони намагаються на добровільній основі та автономно досягти взаємоприйнятного вирішення їхнього конфлікту за допомогою одного або декількох медіаторів [10]. Закон Мальти про медіацію від 21 грудня 2004 року визначає медіацію як процедуру, під час якої медіатор налагоджує переговори між сторонами задля досягнення самостійного рішення стосовно їхнього спору [11].

Отже, проєкт Закону «Про медіацію» № 3504 у визначенні медіації, як відповідні закони Болгарії та Молдови, вказує на позасудовий характер процедури медіації, структурований процес, як визначено у законі Німеччини, що реалізується за добровільною згодою сторін (Німеччина, Болгарія тощо) між сторонами за сприянням третьої (Молдова) сторонньої (Польща) особи ( медіатора) на конфіденційній основі задля врегулювання спору.

Медіації як певній процедурі притаманні ознаки, серед яких слід виділити такі: наявність правового спору між сторонами; вирішення спору та винесення рішення безпосередньо сторонами; наявність третьої особи (медіатора), який сприяє налагодженню комунікації між сторонами, однак не вирішує спір по суті; відсутність жорсткої правової регламентації процедури; наявність медіаційної угоди та неможливість примусового іiї виконання без звернення до компетентних органів [12].

Загалом у юридичній літературі виділяють різні моделі медіації, які відрізняються процедурою розгляду, відображають різноманітні теорії, види й стратегії. I. Ясиновський зазначає, що залежно від ролі медіатора в процедурі медіації Р. Фолкнер, К.-Х. Спарін і Дж. Томас виділяють такі чотири моделі медіації:

- «модель рятівника», де медіатор не має спеціальних професійних знань і навичок, допомагає вирішити незначні, переважно побутові конфлікти;

- модель, у якій медіатор відіграє роль посередника й виступає третьою стороною 
у спорі; він створює атмосферу конструктивної співпраці та дбає про коректне ставлення сторін одна до одної, сприяє реалістичній оцінці ситуації сторонами, прийняттю адекватного рішення тощо;

- модель, де медіатор для вирішення конфлікту може використовувати будь-які засоби та методи, зокрема маніпулювати сторонами;

- модель, де медіатор виступає в ролі організатора вирішення конфлікту [13].

В Україні пропонується запровадити останню модель, яка набула найбільшого поширення.

Аналіз проєкту Закону «Про медіаиію» № 3504 .

Проєкт Закону «Про медіацію» № 3504, внесений Кабінетом Міністрів України, 15 липня 2020 року Верховна Рада в першому читанні прийняла за основу. Поданий проєкт має як переваги, так і недоліки. Безумовною перевагою законопроєкту є визначення медіації як добровільної та позасудової, що відповідає загальним принципам медіації, що визначені Директивою 2008/52/ЕС.

Водночас проєкт Закону «Про медіацію» № 3504 не розглядає можливості проведення медіації кількома медіаторами одночасно, що допускається, наприклад, у законодавстві Німеччини та Казахстану.

Загалом, незважаючи на досить детальну регламентацію правового статусу медіатора, проєкт Закону «Про медіацію» № 3504 залишив поза увагою визначення поняття сторони медіації, моменту, з якого особа набуває такого статусу, а також не вказує на можливість здійснення медіації адвокатами чи нотаріусами, а також не визначає правовий статус об'єднань медіаторів. 3 огляду на обсяг статті питання про правовий статус медіатора не розглянуто, адже воно потребує окремого дослідження.

Окрім того, процедура проведення медіації врегульована досить поверхово. Так, у статті 2 проєкту Закону «Про медіацію» № 3504 визначено сферу застосування медіації. Проте спори, у яких медіація не застосовується, визначені лише загалом: «у спорах (конфліктах), якщо такі спори (конфлікти) впливають чи можуть вплинути на права і законні інтереси третіх осіб, які не беруть участі у медіації, та в інших випадках, передбачених законом». Проте станом на сьогодні у законодавстві такі винятки не визначено. Необхідно передбачити принаймні найбільш важливі сфери, де медіація не може бути застосована, що дасть змогу уникнути вільного тлумачення того, чи можуть «такі спори» вплинути на права й законні інтереси третіх осіб, які не беруть участі у медіації.
Визначаючи сферу застосування медіації, маємо враховувати, що, відповідно до положень статті 1 Директиви 2008/52/ЕС, вона не поширюється на податкові, митні та адміністративні спори чи відповідальність держави за дії чи упущення під час здійснення державної влади.

Окрім того, відповідно до частини 1 статті 2 проєкту Закону «Про медіацію» № 3504, медіація може застосовуватись у «будь-яких конфліктах (спорах), які виникають у цивільних, сімейних, трудових, господарських, адміністративних правовідносинах». Проте відповідні процесуальні кодекси та практика не оперують поняттям «конфлікт», застосовуючи поняття «спір».

У наукових працях щодо медіації зазначено, що «конфлікт - насамперед поняття філософське, соціологічне та психологічне. Це слово означає протиріччя між людьми або їх групами і спільнотами (не обов'язково щодо їх юридично закріплених прав). Спір зовнішній і формальний прояв конфлікту: сторони висувають взаємні претензії, або одна сторона заявляє про своє право і висуває певну вимогу, а інша заперечує у першої наявність такого права і відмовляе у задоволенні цієї вимоги» [14].

Г. Севастянов зазначає, що під час застосування методу вирішення спору спір вирішується щодо наявних прав і обов'язків сторін (правовідносин сторін), а під час врегулювання конфлікту сторони прагнуть узгодити свої інтереси й досягти взаємоприйнятного припинення конфлікту [15]. При цьому врегулювання конфліктує метою медіації, тоді як медіація є методом вирішення спору.

В. Самохвалов розглядає медіацію одночасно і як «процес розв'язання конфлікту, в якому незалежна третя сторона, що називається медіатором або посередником, сприяє добровільній взаємовигідній згоді під час вирішення спору між сторонами конфлікту», і як «метод вирішення спорів, за яким незалежна третя особа (медіатор) допомагає сторонам дійти прийнятного варіанта вирішення спору, сприяючи їх порозумінню, вносячи зрозумілість в узгоджені та спірні питання, допомагаючи їм зрозуміти позиції одна одної, пропонуючи варіанти врегулювання тощо» [16, с. 176].

О. Кисельова, розглядаючи співвідношення понять «трудовий спір» і «трудовий конфлікт», доходить висновку, що конфлікт є першопричиною спору і породжує його [17].

У практиці застосування медіації в Україні зазвичай під час здійснення медіації у приватно-правових відносинах говорять про вирішення, рідше врегулювання спору, 
тоді як у відносинах міжнародних, а також публічних частіше говорять про врегулювання конфлікту. Отже, оскільки проєкт Закону «Про медіацію» № 3504 визначив сферу застосування медіації як приватноправові відносини, то варто використовувати поняття «спір» для позначення сфери його застосування.

Також проєкт Закону «Про медіацію» № 3504 не визначає форми проведення медіації та їі співвідношення з уже наявними альтернативними способами врегулювання спору, зокрема з третейським судочинством, комерційним посередництвом та наявними примирювальними процедурами у трудових, сімейних та земельних правовідносинах, а також не визначає належним чином процес медіації.

Процес медіації складається 3 етапів, кожен 3 яких має свою мету й зміст. Для успішного проведення медіації потрібно, щоби перехід до наступного етапу відбувався після того, як будуть досягнуті всі цілі на попередньому. Виділяють такі етапи процесу здійснення медіації: підготовка до посередництва; вступ у процедуру медіації; обговорення проблеми, пошук та розроблення варіантів вирішення спору; вирішення спору, укладення угоди та підбиття підсумків [18].

У статті 15 проєкту Закону «Про медіацію» № 3504, яка має врегулювати порядок проведення медіації, насправді визначено лише її початок і завершення.

Окрім того, Закон чітко не визначає те, як повинні взаємодіяти учасники медіації та відповідні юрисдикційні органи, що вже задіяні в процесі вирішення конфлікту.

Так, у статті 20 проєкту Закону «Про медіацію» № 3504, що має назву «Медіація під час судового, третейського, арбітражного провадження», не визначено засади взаємодії медіаторів та відповідних судових органів (які дії повинні вчинити сторони процесу, суд та медіатор, а також які це матиме процесуальні наслідки), а також не передбачено забезпечення наявності у відповідних судах інформації про медіаторів.

Окремо постає питання правового значення угоди про врегулювання конфлікту (спору) за результатами медіації. Так, частиною 2 статті 20 проєкту спільне рішення сторін медіації про врегулювання конфлікту (спору) за результатами медіації (яке оформлено) може затверджуватися судом, третейським судом, міжнародним комерційним арбітражем в установленому законодавством порядку. Проте іноді, наприклад, якщо за результатами медіації сторони прийняли рішення про часткове задоволення вимог, відповідну угоду доцільніше затверджувати судом.

У статті 1 проєкту угода про врегулювання конфлікту (спору) за результатами медіації (далі - угода за результатами медіації) визначена як «угода, що фіксує результат домовленості сторін медіації у погодженій ними формі з урахуванням вимог законодавства, в якій сторони можуть вийти за межі предмета конфлікту (спору) за умови, що така угода не порушує захищених законом прав чи інтересів третіх осіб».

Постає низка питань щодо того, чи буде така угода виконуватись виключно на добровільних засадах, чи за її затвердження судом вона матиме статус виконавчого документа. Окрім того, необхідно визначити строки для затвердження іï судом та межі розсуду суду, а також повноваження суду під час затвердження такої угоди за умови, що сторони спору вийшли «за межі предмета конфлікту (спору)». Видається, що в останньому випадку суд відмовить сторонам у затвердженні такої угоди.

Слід погодитися з думкою Г. Огренчук, яка зазначає таке: «щодо правової природи медіаційної угоди, то у разі вирішення спору із застосуванням медіації до порушення справи у порядку цивільного судочинства вона буде звичайним цивільно-правовим договором, який залежно від предмета медіації або створюватиме певні правовідносини, або змінюватиме чи припинятиме чинні» [19], тоді як після початку розгляду справи у суді така угода повинна мати статус, що аналогічний мировій угоді. Саме таке положення міститься у частині 5 статті 27 Закону «Про медіацію» Республіки Казахстан, де зазначається, що «угода про врегулювання спору, досягнута сторонами під час проведення медіації в ході цивільного процесу, негайно направляється судді, у провадженні якого перебуває цивільна справа. Угода про врегулювання спору затверджується судом у порядку, передбаченому Цивільним процесуальним кодексом Республіки Казахстан» [6].

Слушною є думка Я. Любченка, який наголошує на обов'язковому характері угоди за результатами медіації, оскільки «у випадку невиконання чи неналежного виконання договору заінтересована особа може звернутися до суду за захистом своїх порушених прав та/чи законних інтересів» [20, с. 129].

\section{Висновки}

Поняття медіації в проєкті Закону «Про медіацію» № 3504 є відмінним від такого визначення у попередніх законопроєктах. Медіація визначена як добровільна, позасу- 
дова, конфіденційна, структурована процедура, під час якої сторони за допомогою медіатора (медіаторів) намагаються врегулювати конфлікт (спір) шляхом переговорів.

Загалом проєкт Закону «Про медіацію» № 3504 відповідає міжнародним та новітнім національним практикам впровадження медіації і $є$ необхідним для поширення альтернативних способів врегулювання спору. Його запровадження дасть змогу розвантажити судову систему та вирішити окремі конфлікти на досудовому етапі. Модель медіації, яка пропонується законопроєктом, є найбільш оптимальною і допускає застосування медіації як на етапі перед/замість звернення до юрисдикційних органів, так і як спосіб примирення сторін судового процесу. Добровільність медіації, запропонована проєктом, має як переваги, так і недоліки.

Водночас проєкт Закону «Про медіацію» № 3504 потребує вдосконалення. Зокрема, оскільки він не розглядає можливості проведення медіації кількома медіаторами одночасно, залишив поза увагою визначення поняття сторони медіації, моменту, з якого особа набуває такого статусу, а також не вказує на можливість здійснення медіації адвокатами чи нотаріусами, не визначає правовий статус об'єднань медіаторів.

Окрім того, процедура проведення медіації врегульована досить поверхово. Необхідно передбачити принаймні найбільш важливі сфери, де медіація не може бути застосована з урахуванням положень Директиви 2008/52/ЕС про непоширення медіації на податкові, митні та адміністративні спори чи відповідальність держави за дії чи упущення під час здійснення державної влади. Оскільки проєкт Закону «Про медіацію» № 3504 визначив сферу застосування медіації як приватно-правові відносини, то варто використовувати поняття «спір» для позначення сфери його застосування. Необхідно також визначити засади взаємодії медіаторів та відповідних юрисдикційних органів (які дії повинні вчинити сторони процесу, суд та медіатор, які це матиме процесуальні наслідки), а також передбачити правові наслідки укладення угоди за результатами медіації.

Окремого дослідження потребує аналіз законопроєкту щодо визначення статусу медіатора та об'єднань медіаторів.

\section{Список використаних джерел:}

1. Esplugues C. General Report: New Developments in Civil and Commercial Mediation Global Comparative Perspectives. New Developments in Civil and Commercial Mediation / C. Esplugues, L. Marquis (eds). Ius Comparatum - Global Studies in
Comparative Law. 2015. Vol. 6. Springer, Cham. DOI: https://doi.org/10.1007/978-3-319-18135-6 1.

2. Про деякі аспекти медіації у цивільних та комерційних справах. Directive 2008/52/EC. URL: https://zakon.rada.gov.ua/laws/show/994_a95.

3. Про медіацію : Проєкт Закону від 19 травня 2020 року № 3504. URL: http://w1.c1.rada.gov.ua/ pls/zweb2/webproc4_1?pf3511=68877.

4. Шеремет А. Досвід зарубіжних країн щодо впровадження медіації та можливість його застосування в Україні. Часопис Наиіонального університету «Острозька академія». Серія «Право». 2019. № 2 (20) URL: https://j.oa.edu.ua/ articles/2019/n2/19samzvu.pdf.

5. О медиации : Закон Республики Молдова от 14 июня 2007 года № 134. URL: http:// lex.justice.md/viewdoc.php?action $=$ view \& view $=$ do c\&id $=326255 \&$ lang $=2$.

6. О медиации : Закон Республики Казахстан от 28 января 2011 года № 401-IV. URL: https:// online.zakon.kz/document/?doc id=30927376.

7. О медиации : Закон Республики Беларусь от 12 июля 2013 года № 58-3. URL: http://pravo. by/document $/$ ?guid $=3871 \& \mathrm{p} 0=\mathrm{H} 11300058$.

8. Standardy prowadzenia mediacji i postepowania mediatora uchwalone przez Rade w dniu 26 czerwca 2006. URL: https://bip.men.gov. $\mathrm{pl} /$ wp-content/uploads/sites/2/2019/07/standardmediacji-opracowany-przez-spoleczna-rade-ds.alternatywnych-metod-rozwiazywania-konfliktow-isporow-przy-ministrze-sprawiedliwosci-2006-r.pdf.

9. Про медіацію (посередництво) : Закон Болгарії від 17 грудня 2004 року. URL: https:// issuu.com $/ \mathrm{uccg} / \mathrm{docs} / 25$ bulgarian_mediation state act $\mathrm{ukr}$

10. Gesetz "Zur Förderung der Mediationsentwicklung und anderer Methoden der außergerichtlichen Konfliktbewältigung" vom 21.07.2012. URL: https://www.bmjv.de/SharedDocs/Gesetzgebungsverfahren/Dokumente/Gesetz_zur_Foerderung der Mediation und anderer Verfahren der_au\% $3 \overline{\%} \% 9$ Fergerichtlichen_Konfliktbeilegung. pdf? $\quad$ blob $=$ publicationFile \& $=2$.

11. Про медіацію : Закон Мальти від 21 грудня 2004 року. URL: https://justice.gov.mt/en/mmc/ Documents/Chapter 474t.pdf.

12. Цивільне судочинство та медіація. URL: http://vk.com/doc151803367 186297444?hash... $\% \mathrm{E} 2 \% 80 \% 8 \mathrm{E}$

13. Ясиновський I. Характеристика моделей медіації в розвинутих країнах. Юридичний вісник. 2014. № 4 (33). C. 94-98. URL: http://www.law. nau.edu.ua/images/Nauka/Naukovij_jurnal/2014/ statji n4-33 2014/20.PDF.

14. Давыденко Д. Вопросы юридической терминологии в сфере «альтернативного разрешения споров». Третейский суд. 2009. С. 40-53.

15. Севастьянов Г. Теоретические основы альтернативного разрешения споров: концепция частного процессуального права. Хрестоматия альтернативного разрешения споров : учебно-методические материалы и практические рекомендации / сост. Г. Севастьянов. 
Санкт-Петербург : АНО «Редакция журнала «Третейский суд»», 2009. 528 с

16. Самохвалов В. Медіація як інститут відносного й примирного правосуддя. Перспективи застосування альтернативних способів вирішення спорів $(A D R)$ в Украйні : матеріали II Львівського міжнародного форуму (Львів, 26-29 травня 2009 року) / відп. за вип. І. Дутка. Львів : Львівський державний інститут новітніх технологій та управління ім. В. Чорновола, 2009. С. 175-178

17. Кисельова О. Трудові конфлікти та трудові спори: поняття, характеристика, співвідношення. Юридична наука і практика. 2011. № 1. С. 95-99.
18. Мазаракі Н. Медіація в Україні: проблеми теорії та практики. Зовнішня торгівля: економіка, фінанси, право. 2016. № 1. С. 92-100. URL: http://nbuv.gov.ua/UJRN/uazt 2016 111.

19. Огренчук Г. Правове регулювання застосування медіації при вирішенні цивільно-правових спорів : дис. ... канд. юрид. наук : спец. 12.00 .03 Київ, 2016. 213 с. URL: http://elar.naiau.kiev.ua/ handle/123456789/1449.

20. Любченко Я. Альтернативні способи вирішення правових спорів: теоретико-правовий аспект : дис. ... канд. юрид. наук : спец. 12.00.01. Харків, 2018. 254 с

Anzhelika Sheremet. Statutory regulation of mediation in Ukraine: an analysis of the Draft Law of Ukraine "On mediation"

The article focuses on the study of international as well as national experience of mediation legal regulation and on its basis the analysis of the draft Law "On mediation" No. 3504 in order to find ways to improve it. It is determined that harmonization process of the national legislation in accordance with the legislation requirements of the European Union requires the introduction of alternative judicial methods of dispute resolution.

Mediation is characterized by the following features: the presence of a legal dispute between the parties; dispute resolution and decision-making directly by the parties; the presence of a third party - a mediator who facilitates communication between the parties, but does not, in fact, resolve the dispute on the merits; the presence of a mediation agreement, which is executed either voluntarily or compulsorily, in case of its approval by the court.

It is concluded that the draft Law "On Mediation" No. 3504 on the whole corresponds to the international and the latest national practices of mediation implementation. Moreover, it is necessary for the dissemination of alternative dispute resolution and the mediation model proposed by the draft law is the most optimal and allows the use of mediation as a pre-/instead of appealing to jurisdictional bodies, and as a way of reconciling the parties to a lawsuit.

In general, the legal literature distinguishes between different mediation models, which differ in the procedure of consideration, reflect different theories, types and strategies. It is evident that in Ukraine, it is proposed to introduce a model where the mediator acts as the organizer of the conflict resolution.

It is proposed to provide for the possibility of conducting mediation by several mediators simultaneously; to define the concept of the mediation party, the moment from which the person acquires such status; to indicate the possibility of mediation by lawyers or notaries; to the legal status of associations of mediators; to allow for at least the most important areas where mediation cannot be used; to use the term "dispute" to denote the scope of its application; to determine the principles of interaction between the mediators and relevant jurisdictions; to anticipate the legal consequences of concluding an agreement based on the mediation results.

Key words: mediation, alternative ways of dispute resolution, conflict, dispute, agreement, mediation agreement, mediator, draft law. 